\title{
TRIBAL COURTS, THE MODEL CODE, AND THE POLICE IDEA IN AMERICAN INDIAN POLICY
}

\author{
Russel LaWrence Barsh* \\ J. Youngblood Henderson $†$
}

Acting under congressional authority granted eight years ago, the Indian Civil Rights Task Force is at last circulating a draft "Model Code for the Administration of Justice by Courts of Indian Offenses." These courts, originally established under the auspices of the Bureau of Indian Affairs, have been replaced on virtually all reservations by "tribal courts," which are free from Bureau control. ${ }^{2}$ However, tribal courts usually follow procedural codes derived from, if not identical to, those governing Courts of Indian Offenses because the latter are readily available without developmental costs and are assured of the requisite approval of the Secretary of Interior.

The Model Code authorization was enacted as part of the so-called "Indian Bill of Rights," which enumerates those constitutional requirements that Congress, in 1968, deemed it necessary to extend to Indian tribes. ${ }^{3}$ In fact, at that time, Congress had before it evidence that approximately half of all reservation courts were already substantially in compliance with Indian Bill of Rights limitations, and that the perceived "abuses" of reservation courts -absence of the right to counsel, self-incrimination, jury trial, and appeal -were aggravated if not caused by the inadequacy of tribal law and order budgets. ${ }^{4}$ With the passage of the Indian Bill of Rights, tribes instantly experienced increased costs-without any commensurate increase in budgetary assistance-in bringing their procedures up to standard and defending civil rights challenges in the federal courts. ${ }^{5}$ Moreover, a special task force was

\footnotetext{
* Assistant Professor of Business, Government and Society, University of Washington School of Business Administration.

$\uparrow$ Assistant Professor of Native American Studies, University of California, Berkeley.

1. 25 C.F.R. \& 11 (1975).

2. Hearings on Constitutional Rights of the American Indian Before the Subcomm. on Constitutional Rights of the Senate Comm. on the Judiciary, 89th Cong., lst Sess. 50-51, 54-55 (1965). Authority for substituting "tribal courts" for "courts of Indian offenses" is found in 25 C.F.R. \$ 11.1(4) (1975).

3. Act of April 11, 1968, Pub. L. No. 90-284, tit. 11, $\$ 201,82$ Stat. 77. See generally Burnette, Indian Cizil Rights Act, 9 HARv. J. Legis. 557, 595 (1972).

4. Id. at 579, 581-83. But the Bureau denied this charge, Hearings on Constitutional Rights of the American Indian, supra note 2, at 50-51.

5. Between 1966 and 1970, the Bureau of Indian Affairs law and order budget increased rather uniformly from $\$ 2,925,000$ to $\$ 4,952,000$, or 69 per cent. During the same period, reported reservation crimes increased from 63,366 to 106,397 , or 68 per cent. This does not suggest that any substantial investment in upgraded administration was made. BUDGET OF THE U.S. Government, Fiscal Year 1968, Special Analyses app. 577 (1967); Fiscal Year 1969 app. 575
} 
established within the Justice Department to investigate individual complaints against tribes, thus assuring that the cost to a private citizen of prosecuting tribes would be nearly zero. The ultimate result has been extreme reluctance on the part of tribes to engage in aggressive law reform, and a tendency to avoid additional costs by dropping charges against anyone who appears willing and able to bring a civil rights attack on the proceedings. If the tribes follow the Model Code, however, there can be no conceivable challenge in the federal courts, whereas if an independent code is drafted it will be a sure target for federally-subsidized attacks on every section. Congress could not have chosen a better way to neutralize tribal government, or to assure widespread adoption of the Model Code.

An examination of the Model proves that it is nothing more than a redraft of the old Bureau regulations, harmonized with the Indian Bill of Rights largely through borrowings from the American Law Institute's Model Code for Pre-Arraignment Procedure. ${ }^{6}$ No procedural innovations especially suited to tribal needs have been suggested, no substantive improvements in the notoriously antiquated Bureau penal code made, nor necessary expansions of tribal civil jurisdiction provided. But the real significance of the Model Code is that in seeking to cure alleged constitutional errors in the administration of justice it perpetuates errors of a more fundamental nature-historical errors of policy. For three centuries, as an analysis of the Code's historical context shows, the policy of the federal government has been to employ tribal government to defeat tribalism by lodging civil jurisdiction in non-Indian courts while requiring Indians to support and maintain police institutions among themselves.

I

Criminality and the Whole Law

Throughout modern times the development of the criminal law has been intimately linked to the definition and allocation of property rights. According to John Locke, "[t]he great end of men's entering into society being the enjoyment of their properties in peace and safety, and the great instrument and means of that being the laws established in that society, the first and fundamental positive law of all commonwealths is the establishing of the legislative power." John Stuart Mill wrote a century and a half later that the "first" of the duties of government ${ }^{8}$

(1968); Fiscal Year 1970 app. 560 (1969); Fiscal Year 1971 app. 543 (1970); Fiscal Year 1972 app. 561 (1971).

6. Apparently the subcommittee that reviewed the Model Code legislation had this in mind as a modus operandi. Hearings on Constitutional Rights of the American Indian, supra note 2, at 28.

7. J. Locke, The Second Treatise of Government ch. 11, \& 134, at 75 (T. Peardon ed. 1952).

8. J.S. Mill, Principles of Political Economy 239, 243 (D. Winch ed. 1970). See also 5 A. 
is the protection of person and property. There is no need to expatiate on the influence exercised over the economical interests of society by the degree of completeness with which this duty of government is performed. Insecurity of person and property, is as much as to say, uncertainty of the connexion between all human exertion or sacrifice, and the attainment of the ends for the sake of which they are undergone. It means, uncertainty whether they who sow shall reap, whether they who produce shall consume, and they who spare to-day shall enjoy to-morrow.

Has the criminal law ever fulfilled the purposes to which Locke, Mill, and the other progenitors of our republican institutions attributed the duties of government? Reasoning after the fact, Blackstone concluded that crimes had become separately dealt with by the state because they "strike at the very being of society"-the threat to social cohesion exceeds the damage to any individual." Apart from any skepticism that may justifiably attach to this characterization of the great majority of offenses actually before the courts, there is no historical basis for what may be referred to as the conventional theory of criminalization. The separate administration of criminal justice arose as an exercise of royal prerogative, principally to increase crown revenue and displace the autonomy of local, baronial, trade, and merchant courts. ${ }^{10}$

The great wellspring of English law was tort-private actions for damage, principally in the form of trespass. In the diversity of local customs and traditions, tort was prosecuted differently depending upon the jurisdiction invoked by the plaintiff. One of the earliest triumphs, then, of the Crown and common law was the extension to private parties of a royal action of trespass that could be taken in the same form from any jurisdiction, through royal officers, to the royal justices. The sheer military power of the King and his ability to ignore local jurisdictional boundaries made royal writs frequently more attractive to suitors than local suits. Gradually, the authority of the local courts and the applicability of local laws was thereby undermined. The growth of the common law reflects the unification of England under the authority of the King, and the centralization of virtually all rules of policy and morality in London.

One of the chief attractions of the royal writ of trespass was the option of imprisonment of recalcitrant defendants at the King's pleasure, or until they "made fine with the King," which is to say they ransomed themselves. This was the origin both of our concept of the criminal "fine" and the misdemeanor jurisdiction of criminal courts. Gradually the requirement of private

Smith, An Inquiry Into the Nature and Causes of the Wealth of Nations ch. 1, pt. 2 (1776).

9. 5 W. Blackstone, Commentaries *5.

10. See G. Keeton, The Norman Conquest and the Common law ch. 15 (1966); S. Milson, Historical foundations of the Common law 353 (1969); M. Pollack \& F. Maitland, The History of English Law Before the Time of Edward I ch. 8 (1968). 
prosecution disappeared. Today the same activity may be privately prosecuted in tort or publicly prosecuted as a misdemeanor for a fine or imprisonment; indeed we have gone so far as to dispense entirely with the element of private injury, as in so-called "victimless crimes." Sadly, extensive poverty and progress in our regard for the health and safety of prisoners has ceased to make misdemeanor jurisdiction profitable for the state. ${ }^{11}$

Felony jurisdiction had its origins in the Pleas of the Crown, a relatively limited enumeration of very serious matters of which at an early date the King took an exclusive cognizance. Here the Crown enjoyed a forfeiture of the accused's property upon conviction and execution. The reforms that followed our revolution abolished forfeiture as an abhorrent cruelty, but preserved the enumeration and the execution of convicts without modification.

The King's profit on felony was only one of many abuses of criminal justice that helped to precipitate the American Revolution. Most of the colonies were granted original charters that empowered them to exercise exclusive criminal jurisdiction over their subjects. Significantly, a key point in the Crown's program of reasserting its waning authority, years before the Townshend Acts, was the revocation of that exclusive jurisdiction and the requirement that American felons be tried before English courts or before royal appointees under English procedure. Since the list of felonies was then cancerously consuming the misdemeanors ${ }^{12}$-over two hundred crimes were punishable by death-the impact of that policy was profound. As had been the case in earliest England, the assertion of royal criminal justice was manipulated as an instrument of unification and subordination. Unlike their medieval counterparts, however, Americans resisted violently and successfully. Nonetheless it was not the strategy but its application to them that Americans resisted. Preserving the skeleton of English criminal law in the several states, ${ }^{13}$ Americans were within a century to attempt the very same stratagem on the Indians.

11. But even in recent times some American towns have supported themselves out of court receipts, see, e.g., N. Miller \& J. SNell, Why the West was Wild 13 (1963). From the inception of reservation police courts, Indians have tended to be too poor to pay any considerable fines. In 1929 virtually no fines levied by reservation courts exceeded thirty dollars. Hearings on Law and Order on Indian Reservations of the Northwest Before the Senate Comm. on Indian Affairs, $82 \mathrm{~d}$ Cong., 1st Sess., pt. 26, at 14222 (1932). This was still true in our 1973 survey of the Crow Tribes's law and order system.

12. See W. Lee, A History of Police in England (1901)

13. There was a general tendency to adopt or retain English forms and laws both civil and criminal. See, e.g., E. Brown, British Statutes in American Law, 1776-1836, at 24 (1964); G. Wood, The Creation of the American Republic (1776-1787), at 292 (1969); Morris, Legalism versus Reviolutionary Doctrine in New England, 4 New England Q. 195 (1931). Conflict over the retention of British criminal principles was limited to the area of common-law crimes-the power of judges to redefine punishable acts without legislative direction. I E. Warren, The Supreme Court iN United States History 159 (1922). It is highly significant that revolutionary Americans conceived of this as the only fundamental political evil of the criminal process as received from England. 
The institution of the police has a parallel and no less dramatic history. In the contemporary sense of a professional armed force, police were unknown in England or America until the early part of the last century. The earliest forms of "police" were founded on the assumptions that truly dangerous persons were few and known individually, and that citizens had a collective responsibility for maintaining public safety. In Saxon times men were grouped by tens (or tythings). Each tythingman pledged to keep his fellows in order and, failing that, to deliver up the malefactor to the local tribunal for conciliation with and restitution to the victim's family. ${ }^{14}$ Tythingmen were jointly liable for damages and not infrequently also jointly accountable in revenge.

The Normans instituted the first national system of law officers, the sheriffes, but at first their function was merely to administer the tythings. Not until the Assize of Clarendon (1166) were the sheriffes assisted by a jury of twelve for investigation and presentment of felony to a royal court. Needless to say, the system of Norman sheriffes represented an effort at unifying and subjugating the diverse (and for many generations rebellious) communities, many with their own kings, that comprised Saxon England. Nevertheless, the system was almost wholly reliant upon the cooperation of individual citizens. The only enforcement agency at the sheriffe's command, apart from the extraordinary expedient of "summoning the array" (royal troops), was the posse comitatus, or committee of citizens organized to search out fugitives.

Ironically, Norman feudalism swiftly made for the undoing of this national justice system. The Saxons at peace, the invaders turned their attentions to dividing and cultivating their lands, resulting in a redivision of the countryside into essentially autonomous jurisdictions, the manors. The Assize of Northampton (1176) limited the power of the sheriffes over the new landlords, as did Magna Carta.

The evolution of urban concentrations broke down the effectiveness of the tything system and revived interest in organized law enforcement. No longer face-to-face communities, the growing cities experienced a breakdown of the motivation and ability of citizens to check and watch one another. The Statute of Winchester (1285) created the first rotated night watch and required every urban citizen to be armed and ready to be called out by the watch in pursuit of fugitives. Joint liability disappeared. In its stead, wards and parishes were authorized to elect constables on rotation. The principal value of the constabulary was in controlling those incidents of urban prosperity, drunkenness, vagrancy, and petty looting. Unfortunately, the problem in London rapidly outstripped the means appointed to suppress it, and, as the constabulary remained unpaid, its personnel declined accordingly. "In practice . . the

14. T. Critchley, A History of Police in England and Wales ch. 1 (1967); R. Hunnisett, The Medieval Coroner (1961); G. Keeton, supra note $10 \mathrm{ch}$. 15; S. Milson, supra note 10; M. Pollock \& F. Maitland, supra note $10 \mathrm{ch} .8$. 
old principles, devised for a stable, unchanging community, simply broke down." 15 The initial response was an orgy of severity in the criminal courts. "Vagrants and disorderly women ... almost naked, with only a few filthy rags almost alive and in motion with vermin ... unable to treat the constable even with a pot of beer to let them escape, are drove in shoals to gaols."16 Nothing seemed to work. Lawlessness culminated in rioting that verged on insurrection. Parliament at last responded in 1829 with the creation of the "New Police" within the Home Office.

The professional police was therefore an urban concept introduced as a result of the failure of courts alone to preserve order. Traditional criminal law depended on active public cooperation in relatively small, continuous social networks. The civil law, where it provided analogous remedies, was valueless in conditions of general poverty: judgment debtors would have gone to prison anyway. Victim compensation having become virtually impossible, and reconciliation of the offender and the community meaningless, urban law enforcement took on a single direction: systematic deterrence.

When the professional police concept was still new, social theorists predicted that punishment would have a deterrent effect on human behavior. ${ }^{17}$ The utility of the police was to ensure that punishment be swift and certain. However, the same demographic conditions that frustrated the tything and constable-concentration, transiency, and poverty-have made swiftness and certainty an increasingly distant hope. Even more to the point, there is empirical reason to doubt the efficacy of punishment as such. ${ }^{18}$ Punishment, it has been argued, sustains and ritualizes the "solidarity" of the community by branding deviance. ${ }^{19}$ Even if this were true, it would be the best possible indictment of any attempt to extend the criminal law to alien communities enjoying substantially different sentiments regarding order and virtue. An extension of the criminal law system under this theory can, it seems to us, be rationally supported only if it is the instrument of some objective purpose shared by both communities, not merely a symbol of one community's cultural

15. T. CRITCHLEY, supra note 14 , at 21 .

16. C. Reith, The Police Idea 13 (1938), quoting an eyewitness of 1776.

17. Chief among them was Bentham, who argued that punishment should be so devised as to exceed marginally the satisfaction derived from commission of the crime. J. Bentham, Principles of Penal Law, in The Works of Jeremy Bentham pt. 2, bk. 1, ch. 6, at 367 (J. Bowring ed. 1838); J. Bentham, An Introduction to the Principles of Morals and Legislation (J. Burns \& $\mathrm{H}$. Hart eds. 1970).

18. See, e.g., H. Packer, The Limits of the Criminal Sanction (1968); Andenaes, The General Preventive Effects of Punishment, 114 U. PA. L. Rev. 949 (1966); Cramton, Driver Behavior and Legal Sanctions: A Study of Deterrence, 67 Mich. L. Rev. 421 (1969). See also President's Comm. on Law Enforcement and administration of Justice, The Challenge of Crime in a Free SOCIETY Ch. 6 (1968).

19. E. Durkheim, The Division of Labor in Society 93 (G. Simpson transl. 1933); E. Durkheim, The Elementary Forms of the Religious Life 237 (T. Swain ed. 1967). Some recent approbation for this view is found in P. Devlin. The Enforcement of Morals (1965). See also Model Penal Code \& 207.12, Comment (Tent. Draft No. 9, 1959). 
vanity. Similarly, true rehabilitation ${ }^{20}$ necessitates that the motivation or "opportunity" for crime be eliminated and that there be a genuine community for the past offender to return to and be reconciled with.

The criminal law has evolved in an impersonal social environment, the city, in which the reconciliation of disputing parties has been made insignificant by mobility or transiency. ${ }^{21}$ Nothing is done to restore the social network because there is no network to restore. In small communities where mobility is low and disputes tend to arise among neighbors, however, reconciliation may prove a more effective deterrent than punishment. As in the business world, continuity of relationships has real value for co-operation and mutual reliance. Unfortunately, while the civil winner-takes-all rule has given way to arbitration and other conciliatory procedures in business disputes, the criminal law does not officially recognize the importance of continuity and is not structurally differentiated to reflect local patterns of transiency and stability. ${ }^{22}$

To some extent the final redoubt of the criminal law is the inadequacy of civil sanctions against impoverished defendants. This cannot suffice without evidence that punishment has a substantial deterrent effect, and one that is not offset, as some believe, by the alienation and criminalization of some defendants by the corrections process. In cases of poverty, as in cases of selfdestructive behavior such as drug abuse and alcoholism, the question is not so much one of the adequacy of private remedies as the inadequacy of any existing institution.

We conclude, therefore, that the first objective of law should be to assure as far as possible that private relief is inexpensive, readily accessible, and suitable to the ends of compensation and reconciliation. In small, relatively continuous communities, reform can go a long way in this direction.

\section{II}

\section{The Police Idea and Assimilation}

Recognizing the failures of the criminal justice system and its particular inappropriateness in small communities, no pretense can be maintained that

20. On rehabilitation, see The Challenge of Crime in a Free Society, supra note 18 ch. 6 ; Allen, Criminal Justice, Legal Values, and the Rehabilitative Ideal, 59 J. Crm. L.C. \& P.S. 266 (1959). There is reason to believe that we are entering a period of reevaluation of the criminal law. Ironically, many "reform" concepts-such as decriminalization, restitution, and therapeutic confrontation of victim and accused in informal proceedings-were conventional among Indian tribal governments until suppressed by federal authority, and continue to be discouraged by agencies responsible for assisting tribal law enforcement.

21. Several recent sociological studies of urban neighborhoods strongly suggest that transiency, rather than population density, is the urban factor that most contributes to anonymity and lack of cooperation. See, e.g., E. Bott, Family and Social Network (1957); H. Gans, The Urban Villagers (1962); M. Young \& P. Willmot, Family and Kinship in East London (1957).

22. See generally Coons, Approaches to Court Imposed Compromise-The Uses of Doubt and Reason. 58 Nw. U.L. Rev. 750 (1964). 
its imposition on Indian tribes was idealistically motivated. It is difficult not to be impressed by the persistence of the police idea in Indian policy, however, and it is challenging to understand why such an archaic institution was hailed for generations as one of the most efficacious instruments of progress.

When English adventurers first settled the East coast, they made little effort to discover the nature and substance of native laws. Young Henry Spelman, perhaps the first Englishman to live among the tideland tribes of Virginia, apologized in his memoirs that "concerninge ther lawes my years and understandinge, made me the less to looke after bycause I thought that Infidels wear lawless." ${ }^{23}$ Spelman's preconception was shared by most of the commentators of his age. John Smith was to write of Powhatan that neither "[h]e nor any of his people vnderstand any letters wherby to write or read; the only lawes wherby he ruleth is custome." ${ }^{44}$ Nearly a century later, Robert Beverley explained that "having no sort of Letters ... they can have no Written Laws; nor did the Constitution in which we found them, seem to need many. Nature and their own convenience having taught them to obey one Chief, who is arbiter of all things among them." ${ }^{25}$ Dr. Douglass criticized the lack of any "absolute compelling power" among the Indians. ${ }^{26}$

Governed by pure arbitrary will, as Smith and Beverley conceived it, or living in a rude democratic chaos as Douglass and Edmund Burke argued, all observers were happily agreed that the Indians lacked systematic, positive law. ${ }^{27}$ This prompted John Locke and his disciples to reason that, since property is the creature of positive law, societies lacking positive law have no property. ${ }^{28}$ Locke envisaged law as wholly the instrument of social policy and arising only when resources become so scarce that men must agree upon some scheme of allocating them. The absence of law therefore implied an absence of scarcity. The "fact" that Indians had no law conveniently proved

23. Spelman, Relation of Virginea, in Bradley's Arber. Travels and Works of Captaine John Smith, President of Virginia, and Admiral of New England ci, cx-cxi (1965).

24. Smith, A Map of Virginia, With a Description of the Conntry, the Commodities, People, Gozernment and Religion, in Bradley's ARBER, id, at 41,81 .

25. R. Beverley, The History and Presext State of Virginia 225-26 (L. Wright ed. 1947),

26. W. Douglass, a Summary, Historical and Political, of the First Planting, Progressive Improvements. And Present State of the British Settlemexts in NorthAmerica 160 (1760). See also E. Burke, An Account of the European Settlements in America $176(1760)$.

27. This despite abundant evidence from their own mouths of the existence of routine, orderly, customary processes, especially in family law. E.g., R. BeverLeY, supra note 25, at 170-71; W. Byrd, History of the Dividing Line Betwixt Virginia and North Carolina 116 (W. Boyd ed. 1967); Spelman, supra note 23, at cviii; An Account of the Indians in Virginia. 16 WM. \& MARY Q. no. 3, at 288, 233-34 (1959).

28. J. Locke, supra note $7 \mathrm{ch}$. 5. A similar argument is found in C. Molloy, De JURE Maritimo et Navali: Or, a Treatise of Affaires Maritime, and of Commerce ch. 5 (1679); A leading figure in Connecticut land speculation, John Bulkley, popularized Locke in America. J. Bulkley, An Inquiry Into the Right of the Aboriginal Natives to the lands in America, and the Titles Derived From Them (1724). 
that they would not mind giving up a modest portion of their lands to the English.

The idea of lawlessness had an additional implication: that Indians would "need" law once scarcity had been imposed upon them, lest they lapse into uncontrolled robbery and plunder. With some pride Englishmen looked upon their own laws as the most rational, efficacious, and perfect in the whole world, hence they were uncritical of any proposal to loan English laws to benighted pagans. But the colonial government had no illusions that the native tribes would appreciate the gratuity.

As early as 1669, the Governor of New York suggested that frontier villages appoint constables among the Indians "to keep them in $y^{\mathbf{e}}$ better ord ${ }^{\mathbf{r}}$."29 Two years later, settlers at Narragansett petitioned the Executive Council that $^{30}$

seeing $y^{e}$ Indians are numerous among us, Wee propose that $o^{r}$ Governm ${ }^{t}$ may extend to them, \& power to Sumon them to our $\mathrm{Co}^{\text {rts }}$. $w^{\text {th }}$ respect to matt $^{\text {rs }}$ of Trespass, Debt, \& other Miscarriages, \& to Try \& judge them according to our Lawes, when published amongst them.

In reply, the Council cautioned ${ }^{31}$

that They bee carefull to use such Moderacion amongst them, That they be not exasperated, but by Degrees may be brought to be conformable to $y^{\mathrm{e}}$ Lawes; To $w^{\text {ch }}$ End, They are to Nominate and Appoint Constables amongst them who may have staves $w^{\text {th }} y^{\text {e }}$ Kings Armes upon them, the better to keep their People in Awe, \& good Ord ${ }^{r}$. as is practized $w^{\text {th }}$ good Success amongst $y^{\mathrm{e}}$ Indians at $y^{\mathrm{e}}$ East end of Long-Island.

The petitioners evidently were concerned first and foremost with protecting themselves in civil matters involving land acquisition and trade, rather than the good government of the Indians. The Council clearly anticipated resistance. The institution of the native constable was hardly a gesture of respect for tribal autonomy. In the process of choosing the constabulary and giving it the force of crown law, English settlers would have the opportunity to create a new tribal leadership, maintained and protected by the English, through which all commands and favors from the royal government would issue. Established in power and property, it could handily draw allegiance away from traditional tribal leaders and institutions.

Related measures were taken by Massachusetts, which organized Indian townships and appointed Indian officers and judges. ${ }^{32}$ The native court sys-

29. 13 Documents Relative to the Colonial History of the State of New York 430 (E. O'Callaghan ed. 1853-87).

30. I Minutes of the Executive Council of the Province of New York 359 (B. Psaltis ed. 1910).

31. Id. at 362 .

32. Kawashima, Legal Origins of the Indian Reservation in Colonial Massachusetts, 13 AM. J. LEGAL HIST. 42 (1969). 
tem, first established in 1658, provided for trial before an Indian magistrate, appeal to a panel of Indian magistrates under the supervision of an English judge, and transfer of felony cases to the English courts. Apparently the business of the native courts was the suppression of drunkeness, which was prohibited throughout the colony. The General Court of the colony soon promulgated regulations to be enforced by the native courts and eventually replaced them altogether with English justices. To complete the transition, all native officials were subordinated to committees of "trustees" enjoying absolute authority to manage and dispose of the township's natural resources. Non-Indians were permitted to settle on Indian township land and to participate in town meetings. One town survived into the nineteenth century and the state terminated it. ${ }^{33}$

In Connecticut, the Assembly frequently appointed those tribal leaders with whom they would treat. Not only did these instantaneous monarchs enjoy a complete monopoly of English gifts and attentions, but any who protested their absolute rule were punishable for petty treason in the colony courts. In one colorful case, an appointive sachem incurred so much displeasure that his people ransacked and burned his house and ran him out on a rail. On his complaint, the General Court rounded up the dissidents and ordered them to pay compensation and never again question the authority of their pretended sachem. In another, the General Court appointed a committee to draft laws for the use of the Indians-the first model code. ${ }^{34}$ Similar policies were pursued by Maryland and Virginia. ${ }^{35}$

The function and effect of these policies is clear: the alienation of traditional leadership and suppression of traditional law. With native government neutralized and resistance subject to penalty, the way was cleared for the safe confiscation of resources.

The police idea was revived in the west with greater vigor and many added dimensions. Plains Indians already enjoyed a paraprofessional police institution, variously known as "Police Societies" or "Camp Soldiers."36 These

33. W. Apes, Indan Nullfication of the Unconstitutional Laws of Massachusetts pas$\operatorname{sim}(1835)$.

34. See 1 The Public Records of the Colony of Connecticut 299 (C. Hoadley \& J. Trumbull eds. 1850); 2 id. at 39, 56-57,66, 256-57, 440, 483 (native constables "to serve warrants, publish order, and to gather the tribute"); 3 id. at $55 ; 4$ id. at $86,122-23,140,326 ; 5$ id. at $518 ; 6$ id. at $428-29 ; 7 \mathrm{id}$. at $517 ; 9 \mathrm{id}$. at 540. See also 2 id. at 117, a predecessor of the Major Crimes Act, 23 Stat. 385 ( 1885 ).

35. Robinson, Tributary Indians in Colonial Virginia, 67 VA. Magazine Hist. \& Biography 49 (1959); 1 Archives of Maryland 329-331 (W. Browne ed. 1913); 3 Archives of Maryland 360 (B. Steiner ed. 1916).

36. See K. Llewellyn \& E. Hoebel, The Cheyenne Way (1941). Other tribes developed formal court systems without direct federal intervention, e.g., the Cherokee and Iroquois. See J. Noon, Law and Government of the Grand River Iroquois (1949); J. Reid, A Law of Blood: The Primitive Law of the Cheroke Nation (1970); Cherokee advocate, laws of the 
organizations typically functioned only when the entire community was encamped together and, with the exception of certain direct hazards to public welfare such as the scaring off of buffalo, offenders were pressed to make restitution rather than suffer the penalty of destruction of their property. ${ }^{\mathbf{3 7}}$ Because of the size and nature of these communities, identification was simple, prosecution swift, and cooperation, even of the accused, generally assured. Reconciliation was a principal objective of mediation.

Following the Civil War, individual Indian agents experimented with paramilitary native police forces in order to wrest jurisdiction and authority from the Army. ${ }^{38}$ Gradually, the policy gained attention in Washington, and in 1878 a general system of Indian Police was authorized by Congress. Four years later, the Secretary of the Interior promulgated rules for the establishment of native courts-Courts of Indian Offenses-and in 1884 circulated a penal code of reservation offenses.

Perhaps the best introduction to the philosophy of these institutions is found in this advice given to agents: ${ }^{39}$

The chief duty of an agent is to induce his Indians to labor in civilized pursuits. To attain this end every possible influence should be brought to bear, and in proportion as it is attained, other things being equal, an agent's administration is successful or unsuccessful.

In 1873, the Commissioner of Indian Affairs assailed what he called the "fiction of sovereignty" of tribes. ${ }^{40}$

The first condition of civilization is protection of life and property through the administration of law. As the Indians are taken out of their wild life, they leave behind them the force attaching to the distinctive tribal condition. The chiefs inevitably lose their power ... until their government becomes, in most cases, a mere form, without power of coercion and restraint. Their authority is founded only on "the consent of the governed."

\footnotetext{
Cherokee Nation (1852); Commissioner of Indian Affairs, Annual Report 1882, at 133-34 [hereinafter cited as Annual Report]; Humphrey, Police and Tribal Welfare in Plains Indian Cultures, 33 J. Crim. L. \& Criminology 147 (1942).

37. Humphrey, supra note 36 . Ridicule was also an important element of the "correctional" process. W. Hagan, Indian Police and Judges 16 (1966); C. Wissler, Red Man Reservations 133-34 (1971). This also appears to have been true of eastern tribes. Spelman, supra note 23, at cxi, reported that felonies were punishable by death as in England, but a somewhat later narrative of the same Indians concludes that " $\mathrm{t}]$ hey don't punish any crimes with death, only they pay so much money." An Account of the Indians in Virginia, supra note 27, at 243. This is supported by the frequency with which tribes offered to pay restitution to the families of Englishmen killed by Indians, a notable and detailed example being found in S. AmEs, County Court Records of Accomack-Northampton, Virginia 1632-1640, at 57-58 (1954). There are, in fact, instances in which Indians asked that Englishmen condemned to death for the murder of Indians be set free, e.g., H. McIlwaine, Minutes of the Council and General Court of Colonial Virginia, 1622-1632, 1670-1676, at 483 (1924).

38. W. HAGAN, supra note 37, at 25-30.

39. U.S. Dep't OF THE INTERIOR, Regulations $\S 486$, at 84 (1884).

40. Annual Report 1873, at 4-5.
} 
Not unlike his colonial forebears, the Commissioner's argument began with the "fact" of lawlessness and the "need" for law. He was advocating that Congress empower the Bureau to organize "suitable government" on reservations including a police force. ${ }^{41}$ The plan contemplated an immediate transfer of civil and criminal jurisdiction to United States courts so that every Indian "will be effectively protected, by the authority and power of the Government, in his life, liberty, property, and character, as certainly as if he were a white man." 42

A significant change of policy was made in 1877 , leading to congressional approval for the scheme. Indians were no longer to have the benefit of general laws, but were to be subjected to a special code "based upon the result of the experience of those familiar with Indian life and manners." 43 Many reform groups opposed the change, arguing for example that "it would perpetuate the evil ... of keeping Indians apart from all others, and of maintaining a hundred petty sovereignities within our borders. . . The laws which are good enough for all other kindreds and peoples and tribes and nations are good enough for Indians." 44

The reformers were gravely deceived if they believed the official program was anti-assimilationist. Quite the contrary, the problem was that in reality tribes retained their traditional governments and laws and were in no way willing as yet to accept a revolutionary reordering of their affairs. Before the Bureau could effect the absolute transfer of jurisdiction it originally proposed, it had to bring about or accelerate the deterioration of native institutions that it had so confidently assured Congress was already well underway. .

Appropriately, then, the Indian Police and Courts of Indian Offenses took on a subversive (or "educational") character. ${ }^{45}$

The indirect results and ultimate influence of this system are even more important than its direct advantages. Well trained and disciplined, the police force is a perpetual educator. It is a power entirely independent of the chiefs. It weakens, and will finally destroy, the power of tribes and bands. It fosters a spirit of personal responsibility. It makes the Indian himself the representative of the power and majesty of the Government of the United States. . . . The Indians need to be taught the supremacy of law, and the necessity for strict obedience thereto . . where the Indians themsclves are the recognized agents for the enforcement of law, they will the more readily learn to be obedient to its requirements.

41. Axvual Report 1874, at 15 .

42. ANNUAL REPORT 1876, at $\mathrm{x}$.

43. AnNual Report 1877, at 1-2.

44. Board of INdian Commrs. RePort for 1885; W. Hagan, supra note 37, at 159.

45. Axvual. Report 1881 , at xvii-xviii. Compare later reports which attribute the decline of tribal government entirely to natural causes. Anvul Report 1882, at xix; Anvual Report 1883. at $\mathrm{x}-\mathrm{xi}$. 
In a word, "tribal relations should be broken up, socialism destroyed, and the family and the autonomy of the individual substituted." 46

Where agents condescended to approve tribal elections for judge, the purpose was to undermine the traditional leadership succession process. ${ }^{47}$ Elections were bitter and divisive, and understandably so, because of the exclusive power wielded by the winners. More typically, police and judges were appointed by the agent. Great care was taken that they be sympathetic to assimilation. According to the regulations, judges wherever possible were to be able to 'read and write English readily, wear citizens' dress, and engage in civilized pursuits, and no person shall be eligible to such appointment who is a polygamist." 48 Once selected, these officers were given to understand that they were to set a good ${ }^{\circ}$ example and be absolutely obedient to the Agent. ${ }^{49}$ An effort was made to attract the best and the brightest. Police candidates were required to "be of some influence in the tribe." 50 Several expedients were advised to strengthen their allegiance. With higher pay, enlistment would become "a road to distinction, that formerly was the reward of prowess in battle or skill in hunting." 51 Given sixshooters and "a few brass buttons by way of distinction," the Police would be "proud of being considered U.S. soldiers." ${ }^{2}$ Travelling through Indian country towards the close of the nineteenth century, the anthropologist Clark Wissler observed that owing to its power and exploits the Police "rose to such a level of prestige, that every young Indian ... hoped some day to be considered worthy of a place in the troop." 53

In 1892, the Commissioner of Indian Affairs admitted that the police and judges "may be and sometimes are, merely instrumentalities in the hands of the agent for the enforcement of his power." 54 In Wissler's words, "like all good police, they merely obeyed orders." 55 But the police predictably paid a great price for their rise to glory. Although several agents reported from the start that tribes were responding warmly to the police idea, ${ }^{56}$ just as many

\footnotetext{
46. ANNUAL REPORT 1889, at 3-4.

47. W. HAGAN, supra note 37 , at 16 .

48. Secretary of the Interior. Punishment of Crimes and Misdemeanors Committed by Indians, H. R. Exec. Doc. No. 1, 52d Cong., 2d Sess. pt. 5, at 28-31 (1892).

49. E.g. Anival. RePort 1882, at 170, regarding the Yakimas. Agents frequently commended the police for their obedience and loyalty.

50. U.S. DeP'T OF THE INTERIOR, supra note 39, at 108.

51. ANNUAL REPORT 1882. at 31 .

52. ANwual. Report 1877 , at 3; Annual. Report 1882, at xliv. Sep also ANNual. Report 1883, at $26,76-77$.

53. C. Wissler, supra note 37, at 105. See also W. Hagax, supra note 37, at 3; ANNual RePort 1881 , at 145 .

54. ANNUAL REPORT 1892, at 23. In the same year the Board of Indian Commissioners reported that the reservation courts "practically register the decrees of the Indian agent." $W$. HaGaN, supra note 37 , at 110 .

55. C. Wissler, supra note 37, at 99, 104, 106

56. ANNUal Report 1882, at 143. 157; ANNUAl RePort 1883, at 2-3, 84.
} 
observed friction and resistance. Policemen complained of the "enmity and risk" involved, and on many reservations no one could be found willing to undertake a judicial appointment. ${ }^{57}$ Often the resistance was spearheaded by the remnants of the old police societies, as at Cheyenne and Pine Ridge, where they retained considerable authority. ${ }^{58}$ At least at one agency, this was overcome by enlisting the traditional camp soldiers. ${ }^{59}$ Elsewhere opposition to the police idea came from tribal leaders, who "looked upon it as an infringement of their authority" and were often appeased by permitting them to modify the regulations issued by the Secretary. ${ }^{60}$

The Commissioner was fully aware of the intrusive nature of the police idea: $^{61}$

When it is borne in mind that a great majority of the cases upon which they are called to act are offenses committed by their own race against laws made by a race with which they have not hitherto been in sympathy . . . and that many of the regulations established forbid practices which almost form a part of the very existence of the Indian, practices and customs which are to them a religion, and which, if neglected, they believe will result in disaster and death, the impartiality with which the police have performed the duties devolving upon them is creditable in the highest degree.

Some agents were so apprehensive of violent divisions resulting from the introduction of the police idea that they refused to take part in it. ${ }^{62}$ But the aggravation of factionalism was generally understood to be a necessary element in the attack on tribal government. The Osage agent confidently predicted that the police "will gradually but surely destroy the old chieftainship and Indian form of government." 63

Essential to an appreciation of the police idea in the West is the fact that most of the Bureau penal code actually dealt with "heathenish practices" rather than the protection of life and property. In other words, the Court of Indian Offenses code concentrated on victimless crimes. In establishing the courts, Secretary of the Interior Teller condemned ritual dancing as "calculated to stimulate the warlike passions" and lead to the "demoralization of the young, who are incited to emulate the wicked conduct of their elders. ${ }^{64}$ Among the other "great hindrance[s] to the civilization of the Indians" was

57. Annual Report 1882, at 27; Annual Report 1884, at 84; Annual Report 1890, at 105.

58. Stands in Timber, Cheyenne Memories 271, 273 (1972). See also Annual Report 1881 , at xviii; ANnUAl RePort 1890 , at 177.

59. C. WissLer, supra note 37, at 102-03.

60. For example at Umatilla, Washington, Annual Report 1882, at 143 and at Nez Perce, ANNuAl RePort 1883, at 57-58.

61. AnNual Report 1884 , at vi-xvii.

62. E.g., at Grande Ronde, Oregon, Anvual RePort 1882, at 135 ("would only promote discord and contention and strife"), and at Hoopa, California, Annual RePort 1883, at 13 ("mere aggravation of disorder and existing animosities").

63. AnNual Report 1882, at 73, 76, 79; Annual Report 1883 , at 57.

64. U.S. DeP't of THE INTERIOR, supra note $39, \S 496$, at $86-88$. 
the shocking fact that their marriages existed "only by the consent of both parties," and the survival of medicine men, "who are always found with the anti-progressive party" and persist in "using their conjurers" arts to prevent the people from abandoning their heathenish rites and customs." Teller also criticized destruction of the property of the dead as being a disincentive to capitalism. ${ }^{65}$

Consistent with his wishes, the first penal code prohibited dancing, polygamy, practicing as a medicine man, prostitution, and drunkeness. ${ }^{66}$ The only other crime enumerated was stealing, but its purpose is betrayed by the provision that it would be no defense to answer that the property was taken or destroyed in the process of mourning the dead. Traditional inheritance and religion were outlawed in a single blow.

In 1892 the code was revised, with the addition of a catch-all provision empowering the courts to prosecute "any misdemeanor .. . defined in the laws of the State or Territory within which the reservation may be located." 67 The new code also authorized the fine or imprisonment of any Indian who "refuses or neglects to adopt habits of industry, or to engage in civilized pursuits or employments." 68 Tribal reaction was often bitter, but there is reason to believe that native officers were cautious to avoid executing its more objectionable features. At an early stage the courts came to deal more typically with drunkeness and other blessings of compulsory civilization than with resistance to civilized habits. ${ }^{69}$ However, such was the zeal of the Bureau that it strove to make Indians even more moral and law-abiding than their neighbors. ${ }^{70}$ The police idea in the West was more than an Indian policy; it was an experiment in the effectiveness of unlimited police power to shape society.

\section{A. Allotment and Reform}

Reservation government in the 1880 s was purely transitional. In the words of the Supreme Court, its legitimacy was no greater than its usefulness as an

65. This practice survives, for example in the Navajo Nation, alongside a complex system of inheritance rules that have gradually become absorbed into the tribal courts. Shepard, Navajo Inheritance Patterns: Random or Regular?, 5 EThNology 87 (1966); R. Barsh, The Formative Period of Navajo Law: Probate 1940-1972, June 1973 (unpublished manuscript at Kennedy Institute of Politics, Cambridge). In point of fact, very little economic property was ever destroyed, but rather tokens were distributed to all of the mourners in a subtle interplay of guilt and grief, and some personal effects, such as jewelry, were buried with the deceased. Sheep and land remained within the residential unit, descending by locality, not blood.

66. U.S. DeP'T OF THE INTERIOR, supra note 39 , $\S 4-6,8$, at $89-90$

67. H.R. Exec. Doc. No. 1, supra note 48 , at 30 .

68. Id.

69. W. HaGaN, supra note 37 , at 122. A spectacular exception was the thorough suppression of the Sun Dance, described both by Hagan and Wissler, supra note 37. Many individual agents enforced Teller morality with great zeal and in the face of considerable resistance, e.g., AxNuAL REPORT 1883, at 42, 65, 86.

70. According to some observers, it succeeded. AnNual Report 1881, at xix; ANNual Report 
"educational and disciplinary instrumentalit[y]" of the United States. ${ }^{71}$ Accordingly, the jurisdiction of the courts extended only to Indians. What civil powers they enjoyed were required to "conform as nearly as practicable" to rules of state law, and it was their duty to "advise, and inform either or both parties ... in regard to the requirements of these rules." 72

The reservation court system was only five years old when Congress authorized the Secretary of the Interior to allot Indian lands in severalty. ${ }^{73}$ The plan was to reorganize simultaneously the distribution of Indian land ownership along state lines and subject the Indians themselves to state civil and criminal law. It was soon found necessary to postpone the dissolution of reservation government for the duration of the "trust" period during which allottees were incapacitated to dispose of their land. ${ }^{74}$ This may be better understood as a political courtesy to the states unable to tax trust land for the support of services, than an admission that the period of "transition" had been terminated too hastily.

At the same time, Congress provided for federal jurisdiction of certain serious felonies committed by Indians on reservations, allegedly in response to complaints that there remained a dangerous jurisdictional vacuum-an absence of state jurisdiction generally and the limitation of the jurisdiction of Courts of Indian Offenses to misdemeanors. ${ }^{75}$ It must be pointed out, however, that the precipitating incident involved a murderer required to pay restitution by tribal authorities. ${ }^{76}$ Congress's action was more to suppress tribal criminal law than to provide punishment where there had been none.

Repeated extensions of the trust period gave the reservation courts a precarious reprieve for the first third of this century. In the interim, Bureau law and order policy lacked direction. The judges became reactionary and entrenched in their offices. ${ }^{77}$ Although the "overwhelming" share of their business continued to involve drunkeness and minor, typically concensual sex offenses, the Indian courts were also developing or recreating a conciliatory style for resolving bipartisan disputes. ${ }^{78}$ Ironically, to the extent that Indian

1882, at 76; C. WISSLER, supra note 37, at 109; Hearings on Law and Order on Indian Reservations of the Northulest, supra note 11 , at 14208.

71. United States v. Clapox. 35 F. 575,577 (D. Ore. 1888).

72. U.S. DEP'T OF THE INTERIOR, supra note 39 , $\$ 9$, at 90-91

73. General Allotment Act, ch. $119, \S 6,24$ Stat. 390 (1887), as amended, Act of May 8, 1906 , ch. 2348,34 Stat. 182 .

74. 34 Stat. 182 (1906).

75. Major Crimes Act, 23 Stat. 385 (1885).

76. Ex parte Crow Dog, 109 U.S. 556 (1883). According to W. HaGax, supra note 37, at $118-19,123$, traditional restitution procedures persisted for many years after the establishment of reservation courts.

77. C. Wissler, supra note 37, at 138, observed this in the 1890s. Surveys conducted in 1929 found the same to be true; Hearings on Law and Order on Indian Reserzations of the Northzest, supra note 11 , at $14215-216$.

78. "No sharp line ... can be drawn between civil and criminal cases, and often the judgment 
judges of the twenties perpetuated the moralistic fervor of Secretary Teller, they were found to be regarded by younger Indians as backward, paternalistic, and un-American. ${ }^{79}$

Although reservation courts remained cheaper and more readily accessible to Indians than state tribunals after allotment, there were artificial constraints on their powers that rendered them ineffective. In the absence of a systematic policy of interference with their decisions, they were free to evolve procedures for disposing of property and adjudicating commercial matters. ${ }^{80}$ What they lacked, however, was jurisdiction over non-Indians, jurisdiction over "fee patent Indians" within the reservation, and recognition of their judgments in the state courts. Their jurisdiction was thus fragmentary and, without any basis to compel execution of their judgments elsewhere, they offered no security to Indian entrepreneurs or non-Indian creditors. The net effect of the Courts of Indian Offenses was therefore to instill respect for federal power and state law on the criminal side, while providing no meaningful civil protection for Indian property against non-Indians and no basis for the extension of credit to Indians. They maintained tribes in a state of submissive pozerty.

Two years after the publication of his well-known survey of the social conditions of American Indians, ${ }^{81} \mathrm{Dr}$. Lewis Meriam coordinated a study of northwest reservation law and order for the Senate Committee on Indian Affairs. Its major thrust was that the transitional function of the Courts of Indian Offenses had been frustrated by Bureau mismanagement, and that administrative reforms were necessary to assure complete political and legal assimilation at the earliest possible time.

The Meriam study concluded that most Indians were law-abiding and that observed patterns of law-breaking could be attributed in the main to "lack of interests, boredom, poverty, and family and community disintegration." 82 Its

in a single case will give relief of a civil character to the complaining party and provide for the punishment of the defendant." Hearings on Law and Order on Indian Reseriations of the Northwest, supra note 11 , at 14212 .

79. E.g., id. at 14224-225.

80. Some did just that, to judge from the records of this period in the Navajo archives. $R$. Barsh, supra note 65 . Nonetheless on many reservations individual agents maintained their customary grip on the courts. Hearings on Law and Order on Indian Reservations of the Northuest, supra note 11 , at 14213,14224 .

81. L. Meriam, The Problem of Indian Administration (1928).

82. Hearings on Law and Order on Indian Reservations of the Northwest, supra note 11 , at 14142 Summarizing a major statistical study of reservation court business, the study also concluded that Indian crimes were "very rarely . . . of the type from which society must protect itself." $I d$. Virtually all fell into the category of minor victimless crimes. Roughly 50 per cent of all prosecutions were for drunkenness alone, another 16 per cent were for concensual sex offenses such as adultery and fornication. Id, at 14153. Altogether, felonies-larceny, robbery, burglary, arson, rape, murder, and aggravated assault-comprised only three per cent of the business of the Courts of Indian Offenses, and only 11 per cent of all prosecutions of Indians in all courts. What is even more significant is that Indian crime rates for these serious offenses were considerably lower than the national average. U.S. Burfau of the Cexsus, 1932 Statistical Abstract of 
authors were in agreement with the prevalent philosophy of the Depression years that "crime is a symptom of social ill health" and that "society is a party to every offense." 83 Consistent with this view, they suspected that existing "deterrents" such as imprisonment were "essentially superficial" and ineffective. ${ }^{84}$ "Courts and laws can, of course, punish but they are not, unsupplemented, the agencies to remove the causes." 85 The inadequacy of punishment was particularly evident on reservations where "no disgrace" was attached to punishment and where ridicule was as much or a more powerful force. ${ }^{86}$

The great inadequacy of reservation courts in the civil area was observed but not appreciated. For example, it was noted that stealing often merely reflected a dispute over ownership. ${ }^{87}$ Lacking a civil remedy in the Indian court, a person aggrieved over the taking or injury of his property would seize some of his adversary's property in compensation. If this led to a criminal complaint for theft, the Court of Indian Offenses tended to resolve it by trying title, not guilt-it was a jurisdictional fiction, like the nontraversable allegation of vis et armis in common law trespass writs. ${ }^{88}$ Our own study of Navajo courts of the 1920s and 1930s indicates that a large part of the assault prosecutions were in fact boundary disputes in disguise, and were dealt with by the judges accordingly. ${ }^{89}$ The Meriam Commission study concluded, however, that since Indians had a right of access to state courts, the only benefit of tribal civil jurisdiction was that it cost so little to invoke it. They recommended that tribal civil jurisdiction be preserved pending complete termination. They would have limited jurisdiction to cases involving moveable goods of the value of three hundred dollars or less, making it of very little real economic importance. ${ }^{90}$

The central recommendations of the study showed little more progress in policy, though couched in humanistic terminology. "The causes of crime are to be found in the economic and social lives of the offenders." ${ }^{1}$ Indians

The United States 72 (1932). (The text of the Major Crimes Act, $\S 9,23$ Stat. 385 (1885), made it clear that tribes retained a right of original prosecution even for the enumerated felonies.)

83. Hearings on Law and Order on Indian Reservations of the Northwest, supra note 11, at 14148 , 14173.

84. Id. at $14165-167,14183,14216-217$. "We have little faith in the value of punishment . . however . . . we must more or less accept our civilization as it is." Id. at 14226-227.

85. Id. at 14142 .

86. Id. at 14163-164, 14180 ("control through public opinion is much more effective than law enforcement").

87. Id at 14150 .

88. The Meriam team concluded that these "informal sentences," constituting some eight per cent of all judgments, were often "more suited to the needs of the Indians" than the sentences of non-Indian courts. Id. at 14164. Often the defendant was put to work for the benefit of the victim or the community. $I d$, at 14164, 14221-224.

89. R. Barsh, supra note 65.

90. Hearings on Law and Order on Indian Reservations of the Northwest, supra note 11, at 14231, 14196-197.

91. Id. at 14183 . 
committed crimes because they were poor. But while the Commission was willing to attribute some of the problem to the general agricultural depression that had plagued the country for a generation, it was certain that the real cause of poverty was Indianess. "They do not know what they are missing," the investigators lamented, "they lack the incentives to work." ${ }^{2}$ Even where they observed high unemployment in the counties surrounding reservations, the real fault was the Indians' for having avoided migrating to the cities. ${ }^{\mathbf{9}}$ The point was made that the better type left the reservation, leaving behind "the less adaptable, less ambitious, and less able."

Chief among the defects in tribal society were family and community habits that discouraged competitive individualism. For example, "[t]he family is everywhere recognized as the most important of the social institutions affecting the child," and "experience has pretty well proved that the presence of 'in-laws' and other outsiders tends to weaken the bonds between members of the two-generation family and often causes family disruption." 94 Children in extended families tend to be "confused" and "lack a feeling of security and permanence in their lives." 95 This is aggravated by the continual observation of "sponging" by relatives. ${ }^{96}$ In effect, they argued that Indian family life instilled a belief in sharing rather than saving. Recommendation: Social service agencies should do everything possible to motivate Indians to live in nuclear family households. ${ }^{97}$

This objective required the cooperation of law for the reform of the marriage relationship. Dismissing Indian complaints that marriage and divorce were too expensive and sexually oppressive (a very modern theme), the Meriam panel concluded that marriages solemnized under state law were necessary to the Indian economy. They reasoned that the traditional social network depended upon the fact that matriarchal clans controlled most real wealth. Men might come and go as they pleased; the children remained with the mother and her kin because that was where their support came from. But since the "general economy" prefers to make men the source of all wealth, they should be required by means of legal marriage to take sole financial responsibility for their offspring! Graciously, the study did not recommend that compulsion be employed, in the style of the Teller rules. Rather, they advo-

\footnotetext{
92. Id. at 14184. They also explained the economic failure of Indian allottees as due to a lack of "ambition." Id. at 14187 .

93. Id. at 14185 .

94. Id. at 14173

95. Id. at 14174-175.

96. Id. at $14173,14188-189$.

97. Id. at 14234. The Meriam team also criticized Indians' "unearned income" from the lease or sale of trust resources as a disincentive to industriousness. Id. at 14189. We imagine that the coupon-clipping capitalists of the twenties would have been amused by this judgment.
} 
cated a program of persuading them "that they would be happier living in permanent family groups." 98

The Meriam study continued in the tradition of arguing from alleged lawlessness. ${ }^{99}$

The old Indian culture has almost entirely disappeared. The old Indian form of government has gone, tribal authority has broken down, Indian customs and Indian laws are no longer effective. They cannot be restored because the economic basis upon which they rested has been largely destroyed. For these Indians the only way ahead is gradual absorption into or adjustment to the dominant white civilization.

Concededly, this had largely been the responsibility of the "dominant white civilization," but the panel was unwilling to lay the blame on any existing policies. They concluded that there was no racial prejudice against Indians. The frequent failure of off-reservation courts to punish Indians was largely a matter of sympathy, not indifference. ${ }^{100}$ Discrimination was indeed present, but the study suggested that it was rational. The states legitimately resented supplying services to people who could not pay taxes. ${ }^{101}$ More particularly, "we know that people who have nothing to lose constitute a danger to those with possessions; that in any community the lower standards of life tend to depress the higher." ${ }^{112}$ There is a certain ring to this that is reminiscent of the anarchism scare in the twenties, especially where the report compares non-Indian values in privacy, acquisitiveness and private property with Indian gregariousness and communalism.

If followed that "[t]he task of helping the Indians to become adjusted is educational. In the matter of law and order the lesson they have to learn is to know, respect, and observe the laws of the State in which they reside."103 A reorganization of the reservation court system was proposed consistent with this philosophy. To begin with, each court was to have a non-Indian chief judge, because Indian judges "alone could not well apply State law or themselves educate the Indians to prepare for the ultimate transition to State law."104 Indian associate judges were nonetheless considered "useful." It would prove an "educational" experience for them; moreover they could be elected so that the community would "feel they had a real part in the court" and be "train[ed]" in the electoral process.

Since Indian offenders "need more help than punishment," the court system was to be integrated with Bureau social services. ${ }^{105}$ Social workers were to

\footnotetext{
98. Id. at 14175-177.

99. Id. at 14142 .

100. Id. at $14200-204,14181$.

101. Id. at $14182-183,14207$.

102. Id. at 14182,14190 .

103. Id. at $14138,14139,14142$.

104. Id. at 14139, 14230.

105. Id. at 14164 .
} 
be assigned to each court, and in some cases even sit as judges. ${ }^{106}$ This was not necessarily an effort to be progressive. There is, for example, a certain element of "behavior modification" in the suggestion made that "law enforcement does build up a certain respect for law, whether or not the law is of the group's own making." 107

Naturally, the law of the reservation was to be state law because of its "educational value." 108 Its administration by Indian courts was to be strictly transitional, to ease the change by degrees. A special code of Indian misdemeanors was to be promulgated by the Bureau, but its function too was conceived of as transitional. "As most of the offenses committed by Indians are of the minor character usually covered by municipal and township ordinances and not by State laws, and as such organized governmental units do not exist on many reservations," the code would have to serve until such time as Indians could join with non-Indians to form their own townships under state law. ${ }^{109}$ As for tribal government, its value had become purely "recreational."11"

"We must popularize rather than compel" was the theme of much of the report." But as Depression-era liberals, its authors must have had some doubts about the perfection of the American institutions they planned to sell. "It is true," they admitted, "that some of our traditional institutions are at present under attack. . . It is not the province of the present investigation to enter into such debate."112 Their object was not to give the Indians wholesome laws, but to make them the same, for better or worse, as everyone else.

These sentiments were shared by many of those who testified before Congress on behalf of the Indian Reorganization Act (IRA) of 1934. ${ }^{113}$ Although Commissioner of Indian Affairs Collier insisted repeatedly that the critical change made by the proposed law was to abolish Bureau despotism and leave Indians free to choose their own laws, Senate Committee Chairman Wheeler of Montana noted that the bill as written provided for no such thing. ${ }^{114}$ Title I required that tribal charters and constitutions be approved by the Secretary

106. Id. at $14139-140$.

107. Id. at 14164. The report-writers appear to have been caught up in the wave of behaviorism that swept American social science in the late twenties. See, for example, their assertion that "[c]ustoms grow out of habits formed because the process of forming them is pleasurable." Id. at 14179-180. Their theory of legal change attributes everything to conditioned responses and nothing to choice or policy.

108. Id. at 14140-141.

109. Id. at 14229 .

110 . Id. at 14177 .

111. Id. at 14179 .

112. Id. at 14226. In all fairness, it should be pointed out that they did accede to some minor variations in reservation courts, but only perhaps for the purpose of minimizing resistance. $I d$. at 14179.

113. Act of June 18, 1934, ch. 567, \$16,48 Stat. 987

114. Hearings on Readjustment of Indian Affairs Before the Senate Comm. on Indian Affairs, 73d Cong., 2d Sess. 31-32, 64-65, 106-07, Collier; 66-67, 106-07, 163-69, Wheeler (1934). 
of the Interior before taking effect, a power that could be, and has in fact been, used to hold up new governments until they comply structurally with Bureau recommendations. ${ }^{115}$ As Collier eventually admitted in his testimony, the net effect of Title I was to protect approved governments from arbitrary revocation by an administrative agency. He assured Congress that it would retain absolute authority to terminate approved tribes. As Wheeler appropriately observed, this gave tribes little more security against the future. ${ }^{116}$

Neither in conception nor enactment did the Indian Reorganization Act materially alter the condition of reservation police and courts. In his presentation Collier insisted that reservation legislatures would have cognizance of only "matters of local concern." He compared it to "town government."117 Of the courts, their "powers at the outset could not be any wider than the powers of the existing court of Indian offenses. The difference would be that it would be a court responsible to the local community." 118 Elimination of Bureau autocracy over law and order would simply assure individual Indians of "due process." Collier and his staff conceded the wisdom of permitting tribes to regulate domestic relations, school administration, and inheritance and agreed that they should be prohibited from making any law inconsistent with that of the State. ${ }^{19}$ Generally, they appear to have been following the advice of the Meriam study, that Indian courts should remain merely as stopgaps in the absence of state municipal organizations.

This impression is reinforced by an examination of Title IV of the bill, which was never approved by Congress. ${ }^{120}$ Title IV established a national Court of Indian Affairs consisting of seven presidentially-appointed judges. The judges were not to be assured that independence of the executive that life tenure provides in the federal court system. Section 14 gave the President, with the consent of the Senate, authority to remove any judge without cause. Thus what appeared to be a component of the judiciary was in reality an administrative agency of the executive department, just like the Bureau.

Jurisdiction of the Court of Indian Affairs was original in the case of violations of the federal criminal code, federal questions, and federal Indian law (such as heirship and allotment, and disputes to which a tribe was a party). At that time all of these matters were heard by United States district courts so

115. This provision of Title I, Act of June 18, 1934, ch. 567, $\S 16-17,48$ Stat. 987, is now codified at 25 U.S.C. $\$ \S 476,477$ (1975). Collier defended this on the grounds that the discretion would be used to grant "more or less" power according to the needs of individual tribes. Hearings on Readjustment of Indian Affairs, supra note 114, at 32.

116. Hearings on Readjustment of Indian Affairs, supra note 114, at 175 .

117. Id. at $65,66,71$.

118. Id. at 69-70.

119. Id. at $69,78,94-95,180,199$. See also Oliver LaFarge's comments, id. at 177, in which Collier apparently concurred by his silence.

120. The text of this part of the bill may be found in Hearings on Readjustment of Indian Affairs, supra note 114, at 11-14. 
that Title IV worked a transfer of existing federal jurisdiction. The Court of Indian Affairs was also to have original jurisdiction over interracial civil disputes involving "commerce" (presumably trade, contract, credit and the like) and over all cases involving the application of tribal ordinances to nonIndians, which we must assume was intended to comprehend both civil and criminal matters. Wherever the court's jurisdiction was original it was also to have jurisdiction of appeals from tribal courts. The court was required by section 12 to apply state law in the absence of a controlling federal law or tribal ordinance; tribal custom or common law was not recognized.

From the beginning, Senator Wheeler's position was that Title IV "is out," nor did Collier present it as "indispensable." ${ }^{21}$ The only explanation Collier could give of the proposal was that it would, in his opinion, avoid the inconvenience of taking certain matters to the district courts and possibly avoid the insensitivity of federal judges to Indian culture. ${ }^{22}$ It would constitute "a special system of courts rather than a special system of substantive law."123

Senator Wheeler was unimpressed. He believed that Indians always got a "square deal" in the state courts and that the federal judiciary "lean backward" to be fair to Indian litigants. ${ }^{124}$ The Court of Indian Affairs was therefore "expensive and unnecessary." 125 More to the point, he persuaded Collier to concede that the proposed court was entirely too small an institution to bear the workload that would be required. ${ }^{126}$ If he was wrong, it was because the structure of the court was calculated to discourage its use. Over the course of a year it could not possibly sit for even a single day in each of the seats of a district court in the United States, nor in the vicinity of each of the nearly 250 Indian reservations existing in 1934. If it chose (as pursuant to section 2 it had discretion to do) to remain in the nation's capital, or to sit in only a dozen or so cities or towns, it would be at least as inconvenient as the district courts.

A more damning feature of Title IV was its potential impact on Indian

121. Id. at $136,208$.

122. Id. at 33, 205 ("basic reason for this is . . convenience"). Collier also suggested that Title IV would extend judicial review to Bureau administrative actions, but this could have been accomplished much more simply by amending the general delegations of power to that agency. Act of July 9, 1932, ch. 174, $\$ 1,4$ Stat. 564; Act of July 27, 1868, ch. 259, $\$ 1,155$ Stat. 228, and in fact was ultimately achieved through the courts in Tooanippah v. Hickel, 397 U.S. 598 (1970).

123. Comments of Alexander Holtzoff, in Hearings on Readjustment of Indian Affairs, supra note 114 , at 207 .

124. Id. at $140,208$.

125. Id. at 146,170 .

126. Id. at 139, 197. On the basis of the Meriam study, Hearings on Law and Order on Indian Reservations of the Northwest, supra note 11, at 14153, not fewer than five thousand cases were heard in 1929 on reservations from which appeals could have gone to the proposed Court of Indian Affairs. There is no way to estimate the number of additional cases that might have been brought by virtue of the new court's original jurisdiction. Today, reservation courts probably handle over one hundred thousand criminal prosecutions alone each year, judging from federal and local statistics. See Budget of THE U.S. Government, supra note 5, and our study of Crow law and order records. 
credit and labor. The jurisdictional incapacities of the Courts of Indian Offenses and their tendency to lack civil laws made non-Indians about as unlikely to extend credit to Indians as the remoteness of state courts and their expense made Indians unable to vindicate their property rights against others. Rather than thrust all interracial cases either into the state or tribal courts to eliminate one or the other of these evils, Collier proposed to remove them all to this special court, which would be even more remote, probably overcrowded, dependent upon presidential whim, and tending to apply state civil law anyway. It could only put a further chill on the Indian economy. But it would tend to preserve the separate supervised status of Indians more surely than either immediate assimilation, which the Wheeler Committee tended to favor, or the unaugmented continuance of the Courts of Indian Offenses which had no statutory authority. Perhaps this is why Collier endorsed Title IV at the same time that he continued to plead with Congress that the lack of capital and credit was the greatest cause of Indian poverty and the most important objective of reorganization. ${ }^{127}$

Without Title IV, Title I of the Indian Reorganization Act merely authorized tribes to replace the Courts of Indian Offenses with courts of their own making, subject always to the same artificial jurisdictional restraints. Since it was jurisdiction and enforcement power that contributed most to the valuelessness of the old courts in civil matters, the IRA had the effect of shifting the apparent responsibility for the failures to the Indians themselves. Tribal government assumed political accountability for the court system but was not given the most essential powers necessary to make it work, nor did the Bureau provide research and drafting subsidies to tribal lawmakers except in the form of pre-packaged "tribal codes" that read conspicuously like the Courts of Indian Offenses regulations. Reorganization renewed the policy of education. Tribal courts would be required in the approval process to behave like state courts but would have no power. Instead of attacking the Bureau, dissident tribal members would attack the tribal leaders who appeared immediately responsible, hastening the discreditation of all tribal government and its eventual demise. ${ }^{128}$

Because of tribal poverty and the absence of a suitable tax base-precisely the "legitimate" reason for state reluctance to assume responsibility-tribal law and order would continue to have to be subsidized in large part by the Bureau. On many reservations judges continue to receive their paychecks

127. Hearings on Readjustment of Indian Affairs, supra note 114, at 73, 74 .

128. We suggest that the confrontation of tribal officers and dissidents in the recent Wounded Knee incident was a manifestation of the consequences bred by this process of fostering easily discredited tribal governments. In 1883 , the Nez Perce agent applauded the Commissioner of Indian Affairs for authorizing agency staff to veto tribal legislation, noting that it would deal a "severe blow" to Indian political unity. Annual RePort 1883, at 56-57. Disguised as "protective," the power of approval and review has been a keystone of federal policy ever since. 
from the Bureau. More significantly, most reservation police forces are paid by the Bureau and commanded by the Superintendent pursuant to federal regulations, precisely as they have been since $1878 .{ }^{129}$ This circumstance is probably aggravated by the separation of powers principles drafted by the Bureau into most tribal constitutions. With no direct appeal or accountability to the legislature, judges and police can tend to respond as obediently to the wishes of the Bureau as the electorate. Since the purpose of separation of powers is to permit the judiciary to defend the people against legislative or executive excess, its place in tribes with town-meeting type governments is completely unwarranted except as another educational mimicry of state government.

Simply because Congress refused to enact Title IV and did enact Title I does not mean that the IRA represents an advance in the principle of tribal sovereignty. Senator Wheeler, perhaps the single most influential supporter of the legislation, considered its use to foster separate tribal laws "a step backward." 130 "[W]hat we are seeking to do . . . is to have these Indians . . . adopt the white-man's ways and laws. . . I do not think you ought to give them the power to set up laws which would conflict with the laws of the United States or of the States." ${ }^{131}$ His reasoning was that real legal differentiation would lead to an intensification of interracial tensions and a further drying up of credit. ${ }^{132}$ This of course assumed that tribal laws would be so different from state laws that it would deter commerce and travel substantially more than state boundaries do. The Committee had no reason to predict that tribes would be so foolish as to use their governmental powers to commit economic suicide, unless they were assuming that Indian leaders were "incompetent" in the strongest sense of the word. What they opposed was differentness, even prosperous differentness. Or were they opposed to the entrenchment of tax exemption and Indian resource management that went along with continued tribal existence?

\section{B. Termination and More Reform}

The Blackfeet, Klamath, Standing Rock Sioux, and Assiniboine complained to Congress that passage of the Indian Reorganization Act would

129. As of 1963, for example, the Sioux reservations of North and South Dakota were between 25 per cent and 100 per cent dependent on federal aid for law and order operations. Hearings on Constitutional Rights of the American Indian, supra note 2, at 113. The Navajo bear 93 per cent of their law and order costs, but they are able to rely on their multi-million dollar natural resource development revenue. Indian Justice Planning Project, The People Will JuDGE (1971). See 25 C.F.R. $\S 11.1,11.3$ (1975), which provides for Bureau fiscal and personnel authority over the Courts of Indian Offenses, and 25 C.F.R. $\$ 11.301$ (1975) regarding police authority.

130. Hearings on Readjustment of Indian Affairs, supra note 114, at 169 .

131. Id. at $177-78$.

132. Id. at $68,170,177-78,198,199-200,208$. See also id. at 98, 152 (Senator Thomas remarks). 
pave the way for complete termination of tribal existence. ${ }^{133}$ They noted that the Act would subsidize and require the consolidation of reservation lands into public (tribal) ownership, minimizing the extent of private Indian ownership. Then, if the tribal charter were ever revoked by Congress, almost all of the tribe's property would instantly become public domain of the state and individual Indians would get nothing. Unfortunately, they were entirely correct.

During the war years and scarcely a decade after passage of the Indian Reorganization Act, there were already suggestions in Congress and the Interior Department that transitional tribal government had outlived its usefulness. ${ }^{134}$ Termination did not come suddenly; it was the culmination of another decade of "transition" during which, in what might appear paradoxical, the Bureau intensified its efforts to organize tribal government and courts but froze investment in capital improvements such as roads, hospitals, and business. ${ }^{135}$ Tribal government was, in effect, being rapidly transformed into a semblance of state government to minimize the impact of and quite probably the resistance to assumption of jurisdiction by the states. At the same time it would have been wasteful for the United States to sink its tax dollars into physical plant that the states would soon have the legal responsibility to provide!

Although termination became "official" in $1953^{136}$ it was executed over the span of another decade on a tribe-by-tribe basis. In the meantime, the tribal court system was given increasing recognition by the federal judiciary. ${ }^{137}$ The Supreme Court quite explicitly regarded it as a transitional instrumentality and, in the same spirit as nineteenth-century decisions, emphasized that this purpose and not popular sovereignty gave them their legitimacy. ${ }^{138}$ Thus, the Court joined the Bureau in graduating Indians into state law, rather than recognizing their separate nature.

Following passage of the Indian Reorganization Act, the Bureau produced a new procedural and penal code for tribes to replace the 1892 regulations. ${ }^{139}$ Pursuant to section 11.1(4) of this model code, a reorganized tribe may substitute its own code of law subject to secretarial approval, which, once again, can

133. Id. at 53. See also id. at 108 (statement of Jesse Rowlodge).

134. See the remarks in U.S. DeP'T OF THE INTERIOR, ANNuAl REPORT for each of the following years: 1946 , at $375-76 ; 1949$, at 338,$366 ; 1950$, at $342-43 ; 1951$, at $353 ; 1952$, at $389-91$; 1953 , at $42 ; 1954$, at 244 .

135. U.S. Dep't OF The Interior, Annual Report 1946, at 376-77; 1951, at 377; Burnette, supra note 3 , at $567-68$.

136. 67 Stat. 588 (1953).

137. E.g., Iron Crow v. Oglala Sioux Tribe, 129 F. Supp. 15 (W.D.S.D. 1955), aff'd, 23l F.2d 89 (8th Cir. 1956); Oglala Sioux Tribe v. Barta, 146 F. Supp. 917 (W.D.S.D. 1956); Williams v. Lee, 358 U.S. 217 (1958).

138. See Williams v. Lee, 358 U.S. 217 . Compare the theory of reservation government here with that of United States v. Clapox, 35 F. 575 (D. Ore. 1888).

139. 25 C.F.R. $§ 11$ (1975). 
be exercised to require near conformity. Coupled with the fact that the Bureau provided little in the way of technical legislative assistance or subsidies, but trained and paid for the police and judges, there was little opportunity or incentive for tribes to expand on the model. Few did to any significant degree. ${ }^{140}$

A brief consideration of the model, as presently amended, that the Bureau now proposes to update is in order. Code courts have not generally been recognized as having jurisdiction over non-Indians, either civil or criminal. ${ }^{141}$ Only recently have some courts recognized such jurisdiction as an inherent element of tribal sovereignty. ${ }^{142}$ Even such criminal jurisdiction as they may exercise over Indians is made expressly concurrent with the state courts when the victim is not Indian. ${ }^{143}$ However, in apparent defiance of the Meriam study and the representations made to Congress by Collier, they are authorized to recognize tribal custom, "not prohibited by federal law," as a rule of decision. ${ }^{144}$ It must, however, be pleaded and proved as a fact if contested, and in the absence of such proof, state law must be applied. The common law development of the court is thereby stifled. The judge is not authorized to draw upon reason, history, or analogy, but can only rely on state precedents and what amounts to anthropological precedents.

The penal code is, to be sure, outdated and overreaching. It prohibits gambling, adultery, fornication, illicit cohabitation, and prostitution but offers

140. Burnette, supra note 3, at 582-83. In its 1968 testimony before the Senate Committee on the Judiciary, Subcommittee on Constitutional Rights, the Bureau represented that it had fulfilled its responsibilities by training Indian police and judges. Hearings on Constitutional Rights of the American Indian, supra note 2, at 50-51. It also represented that most tribes had adopted substitute or modified codes, $i d$. at 62 , although many of them, such as Crow, with which we are familiar, had in fact merely changed the language of the old code, or made a few specific alterations, e.g., popular election of judges, exclusion of undesirables from the reservation.

141. 25 C.F.R. $\$ \S 11.2,11.22$ (1975). The latter section also provides for consent jurisdiction of non-Indians in civil causes.

142. Oliphant v. Schlie, Civil No. 74-2154 (9th Cir., Aug. 24, 1976), held that a tribal court acting under an approved law and order code may exercise concurrent jurisdiction over an offense by a non-Indian on tribal property. Accord, Belgarde v. Morton, Civil No. 74-68-35 (W.D. Wash., filed Aug. 18, 1975). Thereafter, the Solicitor of the Department of the Interior issued a memorandum indicating that reconsideration was being given an earlier Solicitor's opinion holding that tribes have no jurisdiction over non-Indians. 1 Indian L. REP. no. 2, at 51 (1974).

143. Concurrent jurisdiction is compatible with 18 U.S.C. $\S 1152$ (1970). Senate Bill 1 , the Criminal Justice Reform Act of 1975, would delete section 1152 and would tend to weaken the scope of tribal jurisdiction. See Statement of Arthur Lazarus, Jr., in Hearings Before the Subcomm. on Criminal Laws and Procedure of the Senate Comm. on the Judiciary in Opposition to Certain Provisions in S. 1 Relating to Indian Tribes, 94th Cong., 2d Sess., pt. 12, at 236-39 (1975). Some doubt has been expressed whether 18 U.S.C. $\$ 13(1970)$ can be interpreted as authorizing federal prosecution of state law misdemeanors within Indian reservations. Acunia v. United States, 404 F.2d 140 (9th Cir. 1968). Such application would nullify tribal self-government, rendering tribal penal laws that are inconsistent with state laws effectively unenforceable. We read section 203(a)(3) of Senate Bill $l$ to resolve this doubt in favor of applying to reservations a federal misdemeanor identical to that which is applicable to military and park areas.

144. 25 C.F.R. § $11.23(\mathrm{a})(1975)$. 
no remedy for homicide, rape or other serious felonies. As a result of this and the reluctance of federal prosecutors to conduct investigations on reservations, many tribes prosecute Indians accused of these crimes for several counts of assault and battery in order to provide some response. ${ }^{145}$ Astonishingly, the code makes it a crime, punishable by up to three months labor, "to infect another with a venereal disease." There is no requirement of knowledge or of intent. ${ }^{146}$

However the most serious flaw in the old model is on the civil side. Again, in defiance of the understanding with Congress, the regulations do authorize tribes to recognize customary marriage and adoption procedures, determine paternity, punish nonsupport, and distribute non-trust property of deceased Indians. ${ }^{147}$ But family law is only a small part of the civil sphere. What of contract, property and tort law, all of the rules that govern trade and business and regulate the economy of the community? We have two outstanding decisions of the Supreme Court that guarantee a reservation Indian defendant the absolute right to be tried civilly in tribal court. ${ }^{148}$ But the only guidance the Bureau has ever offered to tribes is section 11.24 of the regulations. It amounts to a slim shadow of the tort law. The court is authorized to "fairly compensate" the victim of "careless" injury, penalize willful wrongdoers, and allow the victims of "accidential" damage "a reasonable part" of the loss. We can see a certain conciliatory ideal in the provision for accidental injury, which is of course at odds with the general tort law, but what is the meaning of the section as a whole except to recognize what reservation courts had been doing without interruption since 1878? It adds nothing, and fails either to remedy the defects in court powers, or to provide guidelines for a more comprehensive system of civil laws. There is no authority for enforcing contracts, recognizing or settling the affairs of business associations, or quieting title to property except as ancillary to a suit for injury or a criminal prosecution for trespass or stealing. How indeed could a non-Indian creditor have much security or an Indian entrepreneur adequate protection for his business?

Understandably few civil cases are tried in the majority of reservation courts that remain close to the regulations. On the Crow Reservation in recent

145. In our experience, this has been true in the Crow tribe. See also The People Will Judge, supra note 129.

146. 25 C.F.R. $\S 11.63$ (1975). It has been sporadically enforced even in recent years at the Crow Reservation according to the record of arraignments, probably exclusively as a means of compelling the involuntary commitment of disease carriers.

147. 25 C.F.R. $\$ \$ 11.28-.32,11.64$ (1975). One tribal court has also claimed power to adjudicate the division of trust property between parties to a divorce action. Conroy $v$. Tibbets (Oglala Sioux Tribal Court of Appeals, Dec. 16, 1974), 2 INDIAN L. REP. no. 2, at 54 (1975).

148. Williams v. Lee, 358 U.S. 217 (1958); Kennerly v. District Court, 400 U.S. 423 (1970). One court has also held that the laws of the Navajo Nation are entitled to full faith and credit in state courts although a forum state need not necessarily subordinate its policies to those of another jurisdiction. Jim v. C.I.T. Financial Services, Corp., 87 N.M. 362, 533 P.2d 751 (1975). 
years there have been about three hundred criminal prosecutions for each civil complaint, excluding support and paternity suits. ${ }^{149}$ At the same time, the expense of state process, combined perhaps with its lack of credibility, meant that Crows resorted to it on the average one-third less often than nonIndians in the same county, adjusted for population. ${ }^{150}$ The IRA has changed little for this court system, although the tribe has adopted modifications on the Bureau model. As in 1929, most prosecutions were for drinking and related conduct (73 per cent), and very few for violent crimes that affected third parties (two per cent). ${ }^{151}$ Tribal laws and ordinances are not generally known, cover little in the way of commercial matters, and appear in court in fewer than two per cent of all cases. Safety is not the problem here, nor elsewhere in our experience. Yet the present legal institution is designed, as its name implies, for "law and order"- the police idea.

Some limitations of a constitutional nature on the activities of reservation courts were first proposed as a part of Title IV of the Indian Reorganization Act, which failed to pass Congress. ${ }^{152}$ In the course of hearings held around the country by Senator Ervin's Senate Subcommittee beginning in 1961, a pattern of complaints emerged that focused on abuses of the right to counsel, self-incrimination, jury trial, and appeal. ${ }^{153}$ Often it was apparent that such abuses as did exist had their roots in the financial inability of tribes to foot the cost of public defenders, jurors, investigators and experts, and additional judges. Although the hearings tended to indicate that much more serious abuses were common in cases of Indians before the state courts, ${ }^{154}$ the Committee made no recommendations in that regard, nor did it consider or provide for financial assistance to tribes for upgrading of their judiciaries. Ironically, this sets up a situation in which the standards set for tribal courts could close them down and force all Indian litigation into the state courts where the danger is even greater.

149. Our sample of 7600 recorded complaints, 1968-73. Cf. Shepardson, Problems of the Navajo Tribal Courts in Transition, 24 Human Organization 250 (1965) (95 per cent criminal).

150. Divorce was an exception; Crows resorted to the state courts 60 per cent more than non-Crow's, adjusted for population. This may be explained by the fact that social service agencies require proof of legal divorce, whereas other civil matters may remain entirely between the immediate parties. The Crow tribe has voluntarily relinquished its power to grant divorces.

151. In 1929 some 58 per cent of Crow prosecutions were for drinking and related conduct, and 13 per cent for violent crimes. Hearings on Law and Order on Indian Reservations of the Northuest, supra note 11 , at 14258-259. The rate of violent crimes (per ten thousand) is today comparable to the national average, whereas the rate of victimless crimes such as drunkenness, disorderly conduct, and possession of liquor is far greater. U.S. Bureau of THE Census, 1974 Statistical Abstract of the United States 153 (1974). The fact that Crow, like many reservations, is "dry" contributes significantly to the rates. Although official records do not indicate the degree of intoxication of those prosecuted, our observation of police operations indicated that only a small percentage would have been liable to prosecution under state public drunkenness laws.

152. See Hearings on Readjustment of Indian Affairs, supra note $114, \S \S 9,10$.

153. Burnette, supra note 3 , at 579,581 .

154. Id. at $584-86$. 
In 1965 Senator Ervin challenged the court regulations as "outmoded, impractical, and ... failing to provide for an adequate administration of justice on Indian reservations." 155 His proposed legislative package included constitutional limitations, appeal to the Bureau, a model code, and new procedures for assumption of jurisdiction by the states.

The Bureau responded negatively to the model code idea, but its objection was one of technique and not goals. Representing the Bureau, Solicitor Barry advised that ${ }^{156}$

tribes are widely diverse and that a code appropriate for one tribe might be wholly inappropriate for another. Further, since the long-term objective of the administration of Indian Affairs is to secure the smooth assimilation of the Indian people into our society, I think that Indian codes should conform as much as possible to the substantive and procedural laws of the States in which the Indians live. Since the codes in various States differ, a uniform code for Indian tribes would frustrate this objective.

Note that in the end Barry's objection to uniformity was that the codes should reflect the diversity of the states and not the diversity of tribes. This is a solidly transitional argument, and is reinforced by a conception of the reservation court system that has advanced little beyond the Meriam study. For example, one additional objection to the model was that "a step in the process of . . preparation" for assimilation is "skill and experience in the formulation of legislation," therefore each tribe should draft its own code as an educational experience. "Of course," he conceded, there is the "risk that they will make mistakes," but education is everywhere understood to consist in trial and error! ${ }^{157}$

The Bureau's objections were satisfied by the assurance of the Subcommittee that the model would not be mandatory and would serve only "as a guide." ${ }^{58}$ Beyond that they were in complete agreement. John Baker, Minority Counsel for the Subcommittee, agreed that the function of reservation law was educational, and added his belief that the model code "would be a particularly appropriate vehicle for this education. . . . [Y]ou would serve to steer the tribal council toward existing law." 159 For his part, Barry offered the Subcommittee some advice on the technique of assimilation the Bureau would follow. Rather than take "too long a step" all at once, reservtion jurisdiction should be transferred by Congress to the states "piecemeal." "I think you would find there would be more transferred that way," he concluded. ${ }^{160}$ It is

155. Hearings on Constitutional Rights of the American Indian, supra note 2, at 3.

156. Id. at 20 .

157. Id. See also id, at 26, Barry's comment that tribes should be encouraged to "practice making their own rules" (emphasis added).

158. Id. at 28, 52-53. On behalf of the Bureau, Mr. Barry acknowledged that even without this modification the proposal was not a "disaster" but merely "unnecessary."

159. Id. at 51. Senator Fong remarked, id. at 62 , that he "assumed" that this would be done.

160. Id. at 93-94. See also the remarks of Marvin Sonosky, id. at 131, 136. 
hard to interpret this statement except to mean that the more gradual and insidious the process, the less Indians were liable to resist in Congress and the courts.

The model code issue did not meet much criticism from tribes. Arthur Lazarus, representing the American Association for Indian Affairs, endorsed the model insofar as it would be merely "an example to be set," subject to tribal modification and consent, and principally substantive. The spokesman for the United Sioux Tribes, Cato Valandra, even told the senators that his organization was going to draft its own model "comparable to the State code."161 Apparently the concensus was that the model was to substitute for the assistance tribes had never obtained from the Bureau in order to draft their own codes.

The draft now available betrays that anticipation. In the area of prearraignment procedure, it serves mostly to add detail to the 1934 regulations -as for example to enumerate the contents of a complaint or warrant. Four substantive changes have been made. A procedure is established by which a court officer would screen criminal complaints "for sufficiency."162 This is an extremely dangerous proposition, giving an administrative officer authority, in effect, to refuse to prosecute any complaint made by the victim of a crime, with no appeal being possible from his decision. Weighing this together with the fact that the model does not, as yet, provide any alternative to the old civil procedures, this could serve to chill further the ability of individual Indians to obtain relief from injury.

Next, a requirement that Miranda warnings be given has been inserted. ${ }^{163}$ This is unnecessary because of the application of Miranda to tribes through the due process provisions of the Indian Bill of Rights. The provision of an alternative to arrest by warrant, the summons, ${ }^{164}$ is a commendable step towards informality of the process, and it is in keeping with the recommendation of this procedure by the American Law Institute. Finally, warrantless searches have been authorized, a questionable matter because it actually diminishes the right of privacy of reservation Indians. ${ }^{\mathbf{1 6 5}}$ Of course this may have some law enforcement value, but is it really necessary? As the commentary to the A.L.I. Model Code points out, the development of warrantless search law is intimately connected with drug abuse enforcement because it was found necessary to prevent the destruction of evidence. We are not aware

161. Hearings on Constitutional Rights of the American Indian, supra note 2, at 151 .

162. Proposed Model Code for Administration of Justice By Courts of Indian Offenses $\S 101(\mathrm{c}), 40$ Fed. Reg. 16691 (1975) [hereinafter cited as Proposed Model Code]; $c f$. commentary to sections 121 and 122 .

163. Proposed Model Code $\S 104,40$ Fed. Reg. 16692 (1975).

164. Id. § 105 .

165. 25 C.F.R. $\$ 11.16$ (1975) requires a warrant. 
of that being a problem on reservations. The cost in civil rights could easily exceed any benefits. ${ }^{166}$

The arraignment provisions reduce the time limit on commitment without charges from thirty-six hours to the "next regularly scheduled session of the court." 167 . This is also potentially an abridgement rather than expansion of rights because there is nothing to require that the court meet at least every thirty-six hours. Automatic bail was previously provided by section 11.8; the Model Code enumerates additional kinds of conditions that may be imposed on persons released on bail. ${ }^{168}$

Jury trial may have been limited by a redefinition of those cases in which it may be demanded of right. Old section $11.7 \mathrm{c}(\mathrm{a})$ grants jury trial in any case in which there is a "substantial question of fact," which may be broader than the minimal requirement of federal law repeated in the Model Code, i.e., cases in which the penalty may be imprisonment. ${ }^{169}$ Beyond this, the Model is a more detailed and explanatory expansion of the 1934 regulations, with purely advisory language regarding evidence, stare decisis, and trial format.

Most seriously, there is no position taken on the absolutely critical issue of jurisdiction: whether it shall continue to be fragmentary and limited to Indians or expanded to give the courts that competence and power they need to protect Indian property, as opposed to their liberty. Even to the extent that the Model Code fulfills the laudable objective of protecting Indians from arbitrary and corrupt power, it is not necessarily a break with tradition. It sets Indians against their government and leaves their property, as well as their lives and liberties in many cases, in the hands of foreign courts and legislatures effectively beyond their power to affect. The preconditions for assimilation pressure have only been renewed.

\section{III}

The Virtues of Diversity

The whole course of federal reservation law and order policy has supposed that diversity of law is purely transitional, a necessary delay in the process of assimilation. There has been no hint that diversity may serve any lasting or continuing function in modern society. Yet this flies in the face of the whole structure and history of the United States. The federal system is founded on the principle that diversity can be harmonized with unity, thereby enabling us to enjoy the greatest possible liberty with the greatest possible strength. To successfully deny this constitutional position on diversity in In-

166. Cf. American Law Iinstitute, A Model Code of Pre-Arraignment Procedure $\S$ $120.1,210.1(1975)$.

167. Proposed Model Code $\$ 111$ (b), 40 Fed. Reg. 16694 (1975).

168. Proposed Model Code $\$ \$ 115,116,40$ Fed. Reg. 16695 (1975). Section 115 permits a police officer to release an accused in accordance with a bail schedule supplied him.

169. Proposed Model Code $\$ 124(a), 40$ Fed. Reg. 16699 (1975). 
dian affairs does more than reaffirm that Indians are a people apart, deprived of the ordinary incidents of citizenship. It challenges the security of the states themselves. Little insight into recent affairs is necessary to appreciate the slow collapse of state sovereignty. The federal government has strived for centralization throughout our political system. Regarding tribes, the excuse has been that they are antiquated, inefficient, and even unjust. Of states, much the same has been said. The federal government has been more persuasive in its position on tribes, but do they merely represent the test case of the limits of federal absolutism?

Diversity of law has been with us since the beginning, and we fought at least one war to defend it. By 1750 the American colonies had evolved a dozen different variations on the English common law, variations suited to their individual economies and lifestyles. Early nineteenth-century American jurists would later advance this fact as proof that law was not divine and absolute, but human and flexible. ${ }^{170}$ It spurred us to reshape the political economy we inherited from England because it demonstrated that law grew out of policy rather than logic. But in the years that led to the Revolution, our patchwork law was a great embarrassment to English statesmen. They complained that it threw sand in the gears of the great, uniform, transoceanic commercial empire that English power had built. ${ }^{171}$ Left to their own devices, the colonies threatened to challenge the theory of the intellectual supremacy of British institutions. More to the point, they increasingly sought to fashion laws that would serve their own several interests rather than the King's. In 1776 , diversity of law sounded in treason.

English policy was not so lacking in subtlety that it chose to address the matter directly. Rather, the argument was widely circulated that diversity of law multiplied the costs of commerce. With one law, commerce would flourish to the benefit of all subjects. Property would be protected from confusing problems of ownership and the people would be saved the danger of capricious legislatures making any laws they wished, by the existence of a single, inflexible common law. To join proof with persuasion, Parliament extended uniform laws of trade and navigation to the colonies, appointed their governors and judges to ensure uniformity, and claimed a power to disapprove the acts of their assemblies. Colonies were in some cases aggregated into larger units, and continental agencies were established to administer them.

The Revolution reaffirmed both the independence of the colonies from English supervision and their independence of one another. It vindicated diversity over centralization. The failures of the Confederation did not shake

170. Horwitz, The Emergence of an Instrumental Conception of American Law 1780-1820, 5 Perspectives Am. Hist. 287 (1971).

171. E.g., T. Pownall. The Administration of the British Colonies 105 \& $\mathrm{ch}$. 1 (5th ed. 1774). 
this, so much as it taught us to optimize diversity with security, commerce, and mutual trust.

Of course, England was correct. Diversity is costly. Multiple layers of public administration, jurisdictional boundaries, conflicts of laws, protective and competitive local legislation, all add up to what may be thought of as the price of diversity. Individual liberty has its price. Personal, religious, and political habits may infringe upon the rights and interests of others, but in our constitutional framework this is an acceptable burden within certain limits. Diversity is the price of group liberty.

As long as the general public holds these principles in high regard, and as long as we respect the institution of the states and bear the costs of their differentness, what is the logic of denying the same to Indian citizens? Have we implicitly determined now that fifty is the limit of diversity and freedom in our system of government? The criterion is certainly not fiscal self-sufficiency. If that were the case, many of the nation's cities and several of the states would have, at some time or another, lost their claim to diversity and selfregulation. The distinction cannot be one of history. Tribes are about as truly self-governing today as the American colonies were in 1775; both the original states and tribes have endured a period of political alienation in the chain of their histories. Is the distinction between tribes and the recognized levels of the federal system not one of policy at all, but merely a function of power?

Diversity may actually have three economic virtues: experimental efficiency, administrative efficiency, and distributive equity. The first two tend to make up for the costs of diversity in savings on the operations of government. The last is what we associate with group liberty.

Mr. Justice Brandeis eloquently summed up the importance of experimental efficiency in 1931. Commenting on the radical economic and political controversies arising out of the Depression experience he concluded ${ }^{172}$

The discoveries in physical science, the triumphs in invention, attest the value of the process of trial and error. In large measure, these advances have been due to experimentation. In those fields experimentation has, for two centuries, been not only free but encouraged. Some people assert that our present plight is due, in part, to the limitations set by courts upon experimentation in the fields of social and economic science; and to the discouragement to which proposals for betterment there have been subjected otherwise. There must be power in the States and the Nation to remould, through experimentation, our economic practices and institutions to meet changing social and economic needs. . .

To stay experimentation in things social and economic is a grave responsibility. Denial of the right to experiment may be fraught with serious consequences to the Nation. It is one of the happy incidents of the federal system that a single courageous State may, if its citizens choose, serve as a laboratory and try novel social and economic experiments without risk to the rest of the

172. New State Ice Co. v. Kiebmann, 285 U.S. 262, 310-11 (1931). 
country. ... If we would guide by the light of reason, we must let our mind be bold.

Diversity accelerates the institutional progress of the nation by permitting any number of relatively small, inexpensive innovative reforms to proceed simultaneously. It forces each political subdivision to compare its behavioral assumptions with the experience of others. In general, the system becomes more flexible and capable of more rapid accomodation to what is becoming a more and more rapidly changing environment.

"We suggest that tribes are not vestiges of the past, but laboratories for the future," ${ }^{173}$ in the same capacity as the other political subdivisions of the nation. The depressing historical realization is that to some degree they have always been laboratories of the future, but not by their own wishes or under their own control. Federal autocracy and "progressive" theories of social management and control have been experimented with on Indians throughout the nation's history. Some were disasters, such as the panacea of public education. Many specific programs now proposed for general consumption have had a long history in Indian country, including federal administrative regulation of the economy and socialized medicine. We even hear talk of federal power being used to curb state "parochialism," which is not far different from the doctrine of Indian backwardness. Experimentation ought not to be at the expense of liberty, nor should one community entirely bear the risks and costs of a social experiment for the benefit of another.

Diversity may also promote administrative efficiency. If in fact there are variations in local conditions, uniform administration of general policies cannot be expected to be uniformly effective. A uniform set of guidelines for funding tribal police programs, for example, requires that tribes adopt guideline police systems in order to participate. The result is not to optimize the law enforcement value of each dollar of subsidy but to maximize conformity. Conformity is not in itself an element of social welfare. On the contrary it may have a demoralizing effect and frustrate innovation. The explanation for conformity in Indian affairs however may be that it is cheaper to administer a uniform system, and, the fewer alternatives groups have to provide for their own needs, the more readily they will conform to some condition imposed by government rather than do without subsidy. In social management terms, it is efficient to demand conformity of the poor but not the comparatively wealthy, from the perspective of a bureaucracy seeking to minimize its costs.

By far the most important function of diversity is distributive equity. The civil law best serves the economy in an allocational sense by minimizing "transaction costs," the costs associated with the process of buying and selling.

173. Vine DeLoria Jr., in Hearings on Constitutional Rights of the American Indian, supra note 2. at 195 . 
In a general sense, this entails certainty and predictability of property and contract rules, simple and inexpensive enforcement procedures, and the division of property rights into appropriate units. It may be argued with some justice that these objectives can be accomplished regardless of local conditions, because they depend upon very general attributes of economic behavior and markets. From the point of view of allocation, there is probably not much difference between the best subdivision of water rights into readily transferable bundles in Massachusetts and Nevada, although the value of those units may be considerably different on account of scarcity. We observe, for example, the near unanimous adoption of the Uniform Commercial Code, which had transactional certainty and simplicity as its goal. The fact that Louisiana has not adopted the Uniform Commercial Code, choosing instead to retain its own code, has not, however, undermined commercial transactions across its borders.

But the civil law has never been and can never be purely allocational. The most obvious examples are found in the taxing and zoning powers, which may be used to level income distribution in a community, or to skew it even further. Redistribution need not, however, be so explicit. Contract rules may tend to favor buyers or sellers, merchants or consumers. Property law, in the process of determining original title to things, benefits that class of persons deemed to be the proper owners. The history of American air and water law is replete with reversals in property rules redistributing the benefit of these resources. ${ }^{174}$ Tort rules distribute burdens of care, investigation, and insurance. In many cases these rules have no efficiency effect. Any clear rule would do equally well. ${ }^{175}$ The heart of the matter is that in choosing one rule over another the jurisdiction makes critical, subjective choices regarding the distribution of the enjoyment of its resources, and the nature of its quality of life.

It is because of this process that jurisdiction must always remain a prerequisite of freedom. A policy that is aimed solely at social control through uniform criminal procedures is inadequate: the power to establish and preserve distinctive concepts of material and social welfare within the federal system is equally important. The failure of American Indian policy, as contained in the Model Code, is the failure to take the principles of toleration and responsible social experimentation seriously.

174. See, e.g., the discussion of water policy in J. Hirshleifer, J. Dehaven, \& J. Milliman, Water Supply: Economics, Technology, and Policy (1960).

175. Consider, e.g., Professor Calabresi's perambulations through the economics of the tort law. G. Calabresi, The Cost of Accidents: A Legal and Economic Analysis (1970); Calabresi \& Melamed, Property Rules, Liability Rules, and Inalienability: One View of the Cathedral, 85 HaRv. L. REv. 1089 (1972). 